\title{
Bronchopneumonia by Streptococcus equi subsp. zooepidemicus in a horse with inhalation of pine branch of Araucaria angustifolia
}

\section{Franciéli Adriane Molossi ${ }^{1^{*}}$ (]) Tainah Pereira Dal Pont ${ }^{1}\left(\right.$ Joana Vargas Zillig Echenique $^{1}$ ([)

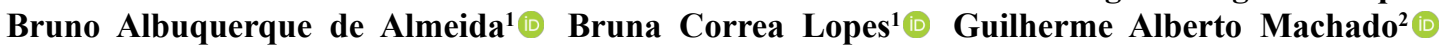 David Driemeier ${ }^{1}$ (1) Saulo Petinatti Pavarini ${ }^{1}$ (이}

\begin{abstract}
${ }^{1}$ Setor de Patologia Veterinária, Universidade Federal do Rio Grande do Sul (UFRGS), 90540-000, Porto Alegre, RS, Brasil, E-mail: francieliadrianemolossi@hotmail.com. "Corresponding author.

${ }^{2}$ Universidade Federal do Rio Grande do Sul (UFRGS), Porto Alegre, RS, Brasil.

ABSTRACT: Respiratory problems due to tracheobronchial foreign bodies (FBs) are unusual in horses; although equines kept in pastures eventually inhale FBs, as conifer twigs of Araucaria angustifolia. A 1,5-year-old Criolle foal was presented with hemoptysis, dyspnea, restlessness and fever $\left(40.9^{\circ} \mathrm{C}\right.$ rectal temperature). Complete blood count showed intense neutropenia, monocytosis, thrombocytopenia and hypoproteinemia. Treatment was carried out but no clinical improvement was observed. At the post-mortem examination, marked amount of dark red liquid was observed in the thoracic cavity (hemothorax). The lung parenchyma was diffusely consolidated, predominantly in the cranioventral area, associated with mild pleural fibrin deposition. The right primary bronchus was obliterated by a Araucaria angustifolia pine branch measuring $18 \mathrm{~cm}$ in length, with adjacent darkened areas (lung consolidation). Microscopically, there was diffuse necrosis with severe hemorrhage in the lungs, associated with marked neutrophilic inflammatory infiltrate, numerous coccoid bacterial aggregates, and fibrinous pleuritis. Additionally, there was diffuse alveolar edema and multifocal thrombosis. Lung fragments were submitted for bacterial culture and mixed bacterial growth was observed with a predominance of Streptococcus equi subsp. zooepidemicus. Inhalation of branches is not commonly reported in horses, but it must be included in the differential diagnoses of pneumonia, and attention should be taken when allowing horses to graze in areas where the plant occurs.

Key words: foreign bodies, equine, bacterial pneumonia.
\end{abstract}

Broncopneumonia por Streptococcus equi subsp. zooepidemicus em um equino com inalação de grimpa de Araucaria angustifolia

RESUMO: Problemas respiratórios devido a corpos estranhos (CEs) traqueobrônquicos são incomuns em equinos, embora cavalos em pastagem possam eventualmente aspirar CEs, como galhos de Araucaria angustifolia. Um potro Crioulo, 1,5 anos, apresentou hemoptise, dispneia, inquietação e temperatura retal de $40,9{ }^{\circ} \mathrm{C}$. O hemograma revelou intensa neutropenia, monocitose, trombocitopenia e hipoproteinemia. O tratamento foi realizado, mas sem sucesso. Na cavidade torácica, foi observada grande quantidade de líquido avermelhado livre (hemotórax). Os pulmões estavam difusamente consolidados, predominantemente cranioventral e com discreta deposição de fibrina sobre a superficie pleural. O brônquio principal direito estava obliterado por um ramo de pinheiro de Araucaria angustifolia com $18 \mathrm{~cm}$ de comprimento. Microscopicamente, notou-se necrose de coagulação pulmonar difusa com hemorragia severa, infiltrado inflamatório neutrofilico marcado, numerosos agregados bacterianos cocoides e pleurite fibrinosa. Fragmentos de pulmão foram submetidos ao isolamento bacteriológico e abundante crescimento misto com predominância de Streptococcus equi subsp. zooepidemicus foi observado. A inalação de grimpas de pinheiro não é comumente relatada em equinos, mas deve ser incluída nos diagnósticos diferenciais de pneumonia e deve-se ter atenção ao introduzir cavalos no campo com a presença da planta.

Palavras-chave: corpos estranhos, equinos, pneumonia bacteriana.

Tracheobronchial foreign bodies (FBs) leading to respiratory problems in horses are rarely reported, with only a few descriptions in the literature (FERRUCCI et al., 2003; URQUHART et al., 1981). Horses kept in pastures are susceptible to aspiration of FBs, and previous descriptions include aspiration of thorny branchlets (BODECEK et al., 2011; FERRUCCI et al., 2003; URQUHART et al., 1981) and conifer twigs (BARUSSI et al., 2020; OGLIARI et al., 2017).

Araucaria angustifolia is a common coniferous species in the family Araucariaceae, which occurs in the southern region of Brazil. $A$. angustifolia has acicular leaves attached to small branches, popularly known as "pine branch" (LORENZI, 2008). When horses aspirate these leaves, 
pulmonary disease may occur and the most frequent clinical signs include chronic cough, purulent nasal discharge sometimes associated with blood, halitosis, intermittent fever and abnormal lung sounds which do not recede after antibiotic treatment (FERRUCCI et al., 2003; MAIR, 2006; URQUHART et al., 1981). Signs of severe pneumonia may also be present (BARUSSI et al., 2020).

In horses, Streptococcus equi subsp. zooepidemicus is considered an opportunistic pathogen, however, in certain situations, this bacterium may cause mild to severe, predominantly suppurative, pneumonia and pleuropneumonia (FULDE et al., 2013; GAEDE et al., 2010). Thus, this study reports a case of bronchopneumonia by Streptococcus equi subsp. zooepidemicus secondary to inhalation of Araucaria angustifolia pine branch in a horse.

A 1.5-year-old Criollo colt was presented with hemoptysis, dyspnea, restlessness and fever $\left(40.9^{\circ} \mathrm{C}\right)$. Complete blood count showed leukocytes within the reference interval (RI) $\left(8.1 \times 10^{3}\right.$ cells $/ \mu \mathrm{L}$; $\mathrm{RI}: 4.9-11.1 \times 10^{3}$ cells $\left./ \mu \mathrm{L}\right)$ with intense neutropenia $\left(0.5 \times 10^{3}\right.$ cells $/ \mu \mathrm{L} ; \quad \mathrm{RI}: 2.5-6.9 \times 10^{3}$ cells $\left./ \mu \mathrm{L}\right) \quad$ and monocytosis $\left(3.6 \times 10^{3}\right.$ cell $/ \mu \mathrm{L}$; RI:0.2-0.6x $10^{3}$ cells/ $\mu \mathrm{L})$. In addition, mild thrombocytopenia $\left(80 \times 10^{3} \mathrm{cell} /\right.$ $\mu \mathrm{L}$; RI:100-250x $10^{3}$ cells $/ \mu \mathrm{L}$ ) and hypoproteinemia (4.9g/dL; RI:5.6-7.9g/dL) were observed. The RI are provided by IDEXX VetLab Station software (version 4.48, IDEXX Laboratories, Inc., Westbrook, Maine, USA). Due to nosebleed, the equine practitioner in charge of the case suspected of bothropic accident and treated the foal with antibothropic serum (1U intravenously), dipyrone, dexamethasone, and fluid therapy with lactated ringer. Nevertheless, the clinical signs worsened and the horse died on the same day of the onset of clinical signs.

At the post-mortem examination, the colt was in good body condition, and ocular and oral mucous membranes were pale red. Negative intrathoracic pressure was absent, and there was a marked amount of dark red liquid in the thoracic cavity (hemothorax). There was diffuse, predominantly cranioventral, consolidation in the lungs, with a light deposition of fibrin on the surface of the visceral pleura (Figure 1). The right primary bronchus lumen was obliterated by an Araucaria angustifolia pine branch measuring $18 \mathrm{~cm}$ in length with adjacent darkened areas of moderate lung consolidation (Figure 2).

Microscopically, the pulmonary parenchyma presented marked diffuse coagulation

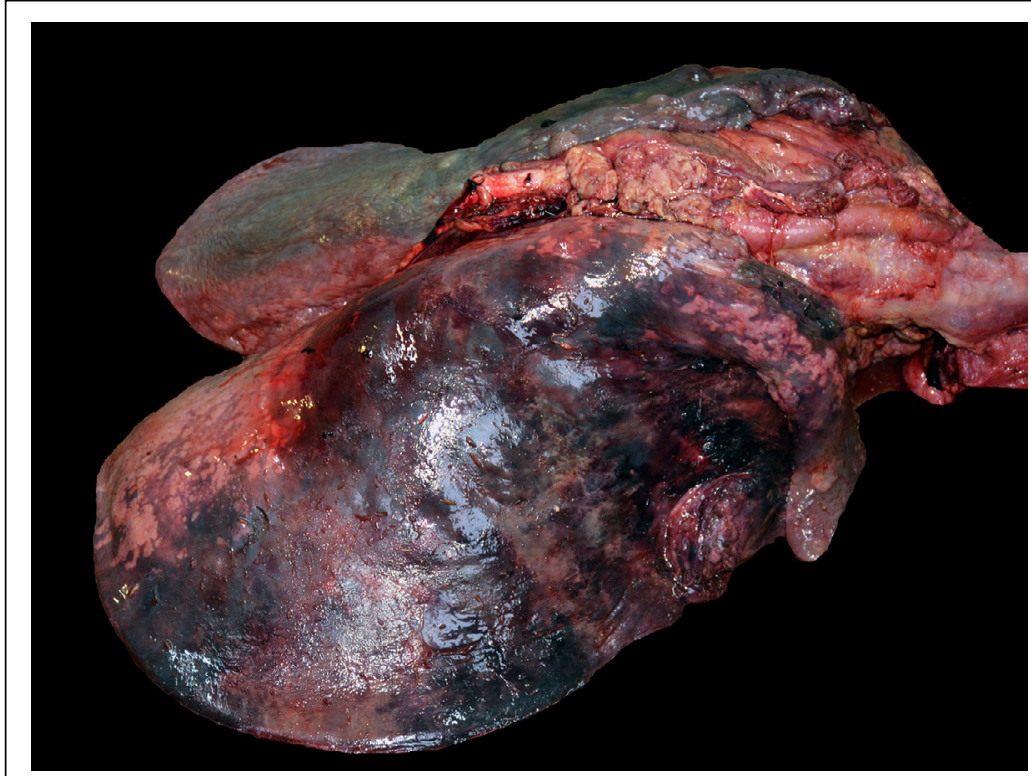

Figure 1 - Bronchopneumonia by Streptococcus equi subsp. zooepidemicus secondary to inhalation of pine branch of Araucaria angustifolia in a foal, gross findings. The lungs are not collapsed, show diffuse pulmonary consolidation, predominantly affecting cranioventral areas, light fibrin deposition on the visceral pleura surface, and areas of black discoloration (hemorrhage). 


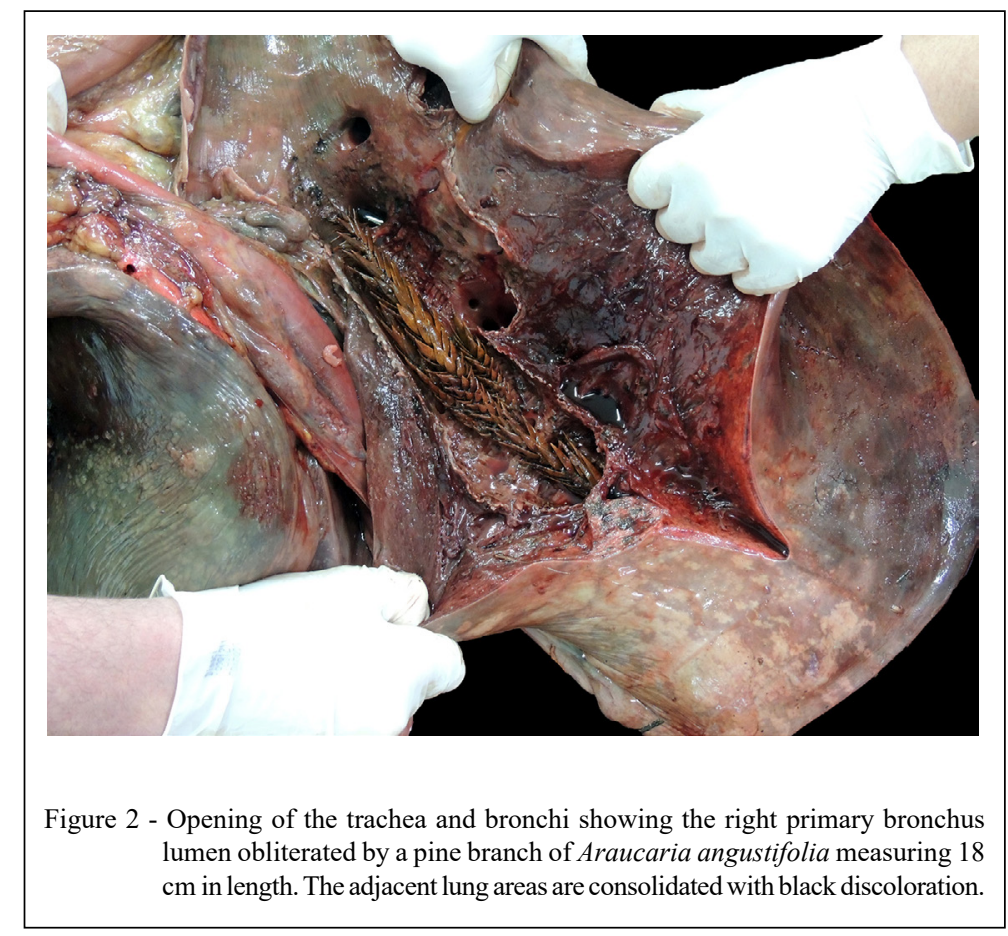

necrosis with intense hemorrhage associated with numerous Gram-positive coccoid bacterial aggregates, confirmed through Gram stain, and fibrinous pleuritis. In addition, severe diffuse neutrophilic inflammatory infiltrate, marked diffuse intra-alveolar edema, and multifocal thrombosis were observed (Figure 3).

Lung fragments were submitted for bacterial culture and plated on Blood Agar (5\% sheep blood; Mueller Hinton, Kasvi ${ }^{\circledR}$, Brazil) and MacConkey Agar (Kasvi ${ }^{\circledR}$, Brazil) followed by aerobic incubation at $37^{\circ} \mathrm{C}$ for 72 hours. Then, bacterial isolates were identified by cultural, morphological, tinctorial, and biochemical characteristics. The differentiation between $S$. equi subsp. equi e $S$. equi subs. zooepidemicus was based on lactose and sorbitol tests, as described by Markey et al. (2013). The culture showed mixed bacterial growth with a predominance of Streptococcus equi subsp. zooepidemicus.

The diagnosis of bronchopneumonia by Streptococcus equi subsp. zooepidemicus secondary to inhalation of Araucaria angustifolia pine branch in a horse was based on epidemiological data, laboratory evaluation, clinical signs, macroscopic and histopathological findings and bacterial culture. Araucaria angustifolia trees occur in the southern hemisphere (MECKE \& GALILEO, 2004). In cattle, inhalation of branches causing respiratory problems has been described by retrospective studies conducted by veterinary pathology laboratories located in the state of Santa Catarina, Brazil. This condition has been reported in the Alto Uruguai Catarinense region with a frequency of $0.89 \%$ of cattle diagnoses (BAVARESCO et al., 2017), and in the mountainous region of Santa Catarina state leading to approximately $1 \%$ of cattle deaths diagnosed by one laboratory (EVANGELISTA et al., 2014). Horses that have access to grazing areas with Araucaria angustifolia trees are susceptible to inhalation of pine branch (BARUSSI et al., 2020). However, horses are highly selective when feeding in the field compared to other herbivores (COLLERY, 1974). This could explain the low occurrence of FBs inhalation in this species.

In our study, dyspnea, hemoptysis, and fever were observed, similarly to previous case descriptions of FBs inhalation in horses (BARUSSI et al., 2020; FERRUCCI et al., 2003; MAIR, 2006; URQUHART et al., 1981). However, these descriptions reported chronic cough, which was not observed in our case, possibly due to the rapid progression of clinical signs. The clinical progression of affected horses may last days (BARUSSI et al., 2020; BODECEK et al., 2011) to months (URQUHART et al., 1981). In our study, we believe that secondary complications (bacterial pneumonia) were directly linked to the rapid clinical progression, which also made the establishment of the clinical diagnosis challenging, since horses with

Ciência Rural, v.52, n.5, 2022. 


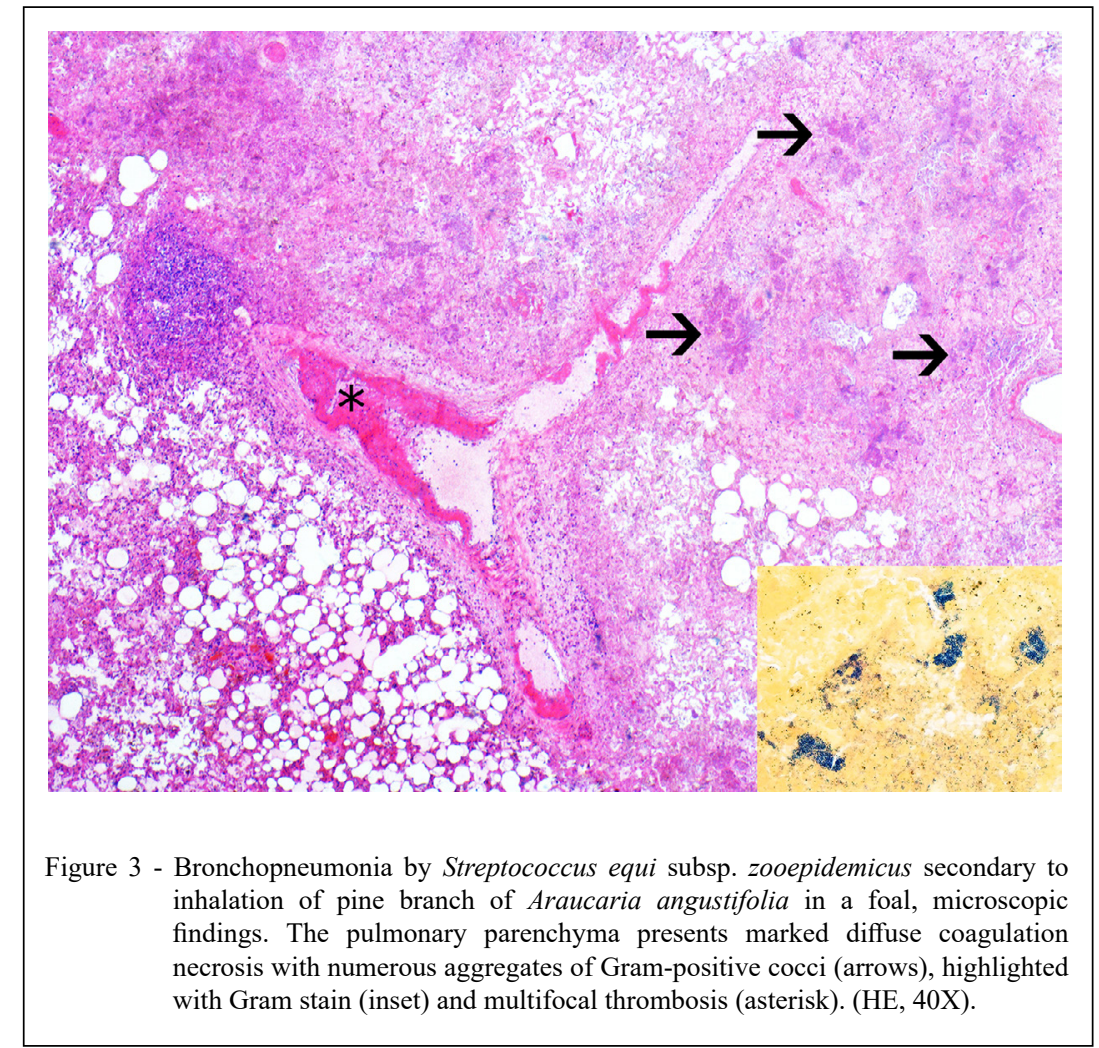

FBs in the respiratory tract may be diagnosed by endoscopy and the removal is commonly successful (BARUSSI et al., 2020).

Findings of post-mortem examinations carried out in fatal cases of FB inhalation in horses include large amounts of free serohemorrhagic fluid in the thoracic cavity, fibrinous pneumonia, with multifocal adhesions between the parietal and visceral pleura (BODECEK et al., 2011). We have seen similar findings in our case, except for adhesions between the pleurae. Additionally, we observed a focally extensive area of cranioventral consolidation, which is characteristic of bacterial origin/etiology, that histologically was characterized by bacterial bronchopneumonia with fibrin deposition and necrosis (CASWELL \& WILLIAMS, 2016).

In our case, the branch was in the right main bronchus, similar to previous descriptions (BARUSSI et al., 2020; BODECEK et al., 2011; FERRUCCI et al., 2003; URQUHART et al., 1981). This probably occurred due to the anatomical peculiarity of the equine respiratory tract, which favors the FB entry directly into the right side due to the right main bronchus and trachea alignment, whereas the left bronchus is slightly inclined (ROBINSON \& FURLOW, 2006).
In horses, Streptococcus equi subsp. zooepidemicus is a commensal bacterium of the upper respiratory tract's mucosa and the lower genital tract (BARQUERO et al., 2010). Therefore, this bacterium may cause opportunistic infections, secondary to primary viral infections, following stressful events or tissue damage (BIANCHI et al., 2020). However, this bacterial agent has also been described as one of the main causative agents of purulent infections in horses and foals (GAEDE et al., 2010; BIANCHI et al., 2020). In our report, we assume that the bacterial infection occurred secondarily to the primary injury caused by the FB, and worsened the respiratory condition leading to death.

Severe pleural and pulmonary injuries associated with exudative fluid accumulation may explain the abnormalities reported in the complete blood count. Leukopenia due to neutropenia is commonly found in peracute or acute peritonitis (MENDES et al., 2000). However, monocytosis increases the leukocyte count, and leukopenia was not seen in our case. Monocytosis is often associated with acute and chronic injury (WALTON, 2013). Additionally, the reddish pleural exudates, occurring due to blood cell leakage, quickly consume the 
platelets after they enter the pleural cavity (RIZZI et al., 2008). Hypoproteinemia is a common finding in horses with acute hemoperitoneum (PUSTERLA et al., 2005). That can explain the thrombocytopenia and hypoproteinemia, respectively, of our case. We suggest that those values may also be present in cases of hemothorax, as observed in this case.

Finally, inhalation of pine branches in horses is not commonly reported, but it must be included in the differential diagnoses of pneumonia in this species. In addition, attention should be taken when allowing horses to graze in pasture areas where Araucaria angustifolia occurs. Furthermore, in this study, we observed the importance of early diagnosis to avoid secondary complications and death.

\section{ACKNOWLEDGMENTS}

The authors are grateful for the financial support that was supplied by Conselho Nacional de Desenvolvimento Científico e Tecnológico $(\mathrm{CNPq})$, Coordenação de Aperfeiçoamento de Pessoal de Nível Superior (CAPES)- Finance Code 001, Fundação de Amparo à Pesquisa do Rio Grande do Sul (FAPERGS), and Próreitoria de Pesquisa da Universidade Federal do Rio Grande do Sul (Propesq/UFRGS)

\section{BIOETHICS AND BIOSECURITY COMMITTEE APPROVAL DECLARATION}

We authors of the article entitled "Bronchopneumonia by Streptococcus equi subsp. zooepidemicus secondary to inhalation of pine branch of Araucaria angustifolia in a horse" declared, for all due purposes, the project that gave rise to the present data of the same has not been submitted for evaluation to the Ethics Committee of the Universidade Federal do Rio Grande do Sul, but we are aware of the content of the Brazilian resolutions of the National Council for Control of Animal Experimentation - CONCEA "http://www.mct.gov.br/index.php/content/view/310553.html" if it involves animals. Thus, the authors assume full responsibility for the presented data and are available for possible questions, should they be required by the competent authorities.

\section{DECLARATION OF CONFLICT OF} INTEREST

The authors have no conflict of interest to declare.

\section{AUTHORS' CONTRIBUTIONS}

All authors contributed equally for the conception and writing of the manuscript. All authors critically revised the manuscript and approved of the final version.

\section{REFERENCES}

BARQUERO, N. et al. Molecular epidemiology of Streptococcus zooepidemicus isolated from the respiratory tracts of Thoroughbred racehorses in training. The Veterinary Journal, mar. 2010. v.183, n.3, p.348-351. Available from: <https://www.sciencedirect.com/ science/article/abs/pii/S1090023308004462>. Accessed: Nov. 20, 2020. doi: 10.1016/j.tvj1.2008.12.013.

BARUSSI, F. C. M. et al. Pine branch of Araucaria angustifolia in horse bronchi: A series of four cases. Equine Veterinary Education, ago. 2020. v.32, n.8. Available from: <https:// onlinelibrary.wiley.com/doi/abs/10.1111/eve.13080>. Accessed: Nov. 20, 2020. doi: 10.1111/eve.13080.

BAVARESCO, L. H. et al. "Grimpa" de Araucária angustifolia como causa de morte em bovinos. In: MOSTRA NACIONAL DE INICIAÇÃO CIENTÍFICAE TECNOLÓGICA INTERDISCIPLINAR (MICTI), 2017, Camburiú, Santa Catarina. Anais..., Camburiú, Santa Catarina: Instituto Federal Catarinense, 2017. p.5. Available from: <https://eventos.fabricadesoftware.ifc.edu.br/media/upload/ submissao/2017/09/20/2017-grimpa-de-araucaria-angustifoliacomo-causa-de-mo 3e00Ewp.pdf $>$. Accessed: Nov. 20, 2020.

BIANCHI, M. V. et al. Causes and pathology of equinepneumonia and pleuritis in Southern Brazil. Journal of Comparative Pathology, ago. 2020. v.179, p.65-73. Available from: $<$ https://www.sciencedirect.com/science/article/abs/pii/ S0021997520300803>. Accessed: Nov. 20, 2020. doi: 10.1016/j. jсpa.2020.07.006.

BODECEK, S. et al. Pleuropneumonia in two horses caused by a tracheobronchial foreign body: Tracheobronchial foreign body in the horse. Equine Veterinary Education, jun. 2011. v.23, n.6, p.296-301. Available from: <https://doi.org/10.111 1/j.2042-3292.2010.00188.x>. Accessed: Nov. 20, 2020. doi: 10.1111/j.2042-3292.2010.00188.x.

CASWELL, J. L.; WILLIAMS, K. J. Respiratory system. In: JUBB, K. V. F. et al. (Org.). Jubb, Kennedy, and Palmer's pathology of domestic animals. Sixth edition ed. St. Louis, Missouri: Elsevier, 2016, V. 2, p. 465-592.

COLLERY, L. Observations of equine animals under farm and feral conditions. Equine Veterinary Journal, out. 1974. v.6, n.4, p.170 173. Available from: <https://doi.org/10.1111/j.2042-3306.1974. tb03954.x>. Accessed: Nov. 20, 2020. doi: 10.1111/j.20423306.1974.tb03954.x

EVANGELISTA, C. M. et al. "Grimpa" de Araucaria angustifolia como causa de morte por insuficiência respiratória em bovinos. In: ENCONTRO NACIONAL DE DIAGNÓSTICO VETERINÁRIO ENDIVET, 2014, Cuiabá, Mato Grosso. Anais... Cuiabá, Mato Grosso: Universidade Federal do Recôncavo da Bahia, 2014. p.2. Available from: $<$ https://eventos.fabricadesoftware.ifc.edu.br/media/upload/ submissao/2017/09/20/2017-grimpa-de-araucaria-angustifolia-comocausa-de-mo_3e00Ewp.pdf>.Accessed: Nov. 20, 2020.

FERRUCCI, F. et al. Use of a transendoscopic technique to remove a bronchial foreign body in a Standardbred colt. Equine Veterinary Education, Out. 2003. v.15, n.5, p.228-232. Available from: <https://beva.onlinelibrary.wiley.com/doi/ abs/10.1111/j.2042-3292.2003.tb00531.x>. Accessed: Nov. 20, 2020. doi: 10.1111/j.2042-3292.2003.tb00531.x.

FULDE, M.; VALENTIN-WEIGAND, P. Epidemiology and pathogenicity of zoonotic streptococci. Current Topics in Microbiology and Immunology, 2013. v.368, p.49-81. Available from: <https://ink.springer.com/ chapter/10.1007\%2F82 2012_277>. Accessed: Nov. 20, 2020. doi: 10.1007/82_2012 277 . 
GAEDE, W. et al. Detection of Chlamydophila caviae and Streptococcus equi subsp. zooepidemicus in horses with signs of rhinitis and conjunctivitis. Veterinary Microbiology, 19 mai. 2010. v.142, n.3-4, p.440-444. Available from: $<$ https://www.sciencedirect. com/science/article/pii/S0378113509005318?via\%3Dihub>. Accessed: Nov. 20, 2020. doi: 10.1016/j.vetmic.2009.10.011.

LORENZI, H. Árvores brasileiras: manual de identificação e cultivo de plantas arbóreas nativas do Brasil. 5a. ed ed. Nova Odessa, SP, Brasil: Instituto Plantarum de Estudos da Flora, 2008.

MAIR, T. Miscelaneous pulmonary disorders. In: MCGORUM, B. C. et al. (Org.). Equine Respiratory Medicine and Surgery. Philadelphia: Saunders [Imprint] Elsevier - Health Sciences Division, 2006, p.601-615.

MECKE, R.; GALILEO, M. A review of the weevil fauna (Coleoptera, Curculionoidea) of Araucaria angustifolia (Bert.) O. Kuntze (Araucariaceae) in South Brazil. Revista Brasileira de Zoologia, Set. 2004. v.21, p.505-513. Available from: $<$ https://www.scielo.br/scielo.php?script=sci_arttext\&pid $=$ S0101-81752004000300013 $>$. Accessed: Nov. 20, 2020. doi: 10.1590/S0101-81752004000300013.

MENDES, L. C. N. et al. Experimental peritonitis in horses. Hematological and biochemistry aspects. Brazilian Journal of Veterinary Research and Animal Science, 2000. v.37, n.2. Available from: <http://www.revistas.usp.br/bjvras/issue/ view/5836>. Accessed: Nov. 20, 2020. doi: 10.1590/S141395962000000200011 .

OGLIARI, D. et al. Aneurisma de aorta secundário à inalação de grimpa de Araucaria angustifolia (bertol.) kuntze em equino. In: XVIII ENCONTRO NACIONAL DE PATOLOGIA VETERINÁRIA - ENAPAVE, 1, 2017, Brasília. Anais eletrônicos..., Brasilia: Savannah Journal of Research and Development, 2017. v.1, p.200. Available from: <https://periodicos.unb.br/index.php/ savannahjournal/issue/view/1035>. Accessed: Nov. 20, 2020.

PUSTERLA, N. et al. Acute hemoperitoneum in horses: a review of 19 cases (1992-2003). Journal of Veterinary Internal Medicine, jun. 2005. v.19, n.3, p.344-347. Available from: $<$ https://onlinelibrary. wiley.com/doi/abs/10.1111/j.1939-1676.2005.tb02705.x>. Accessed: Nov. 20, 2020. doi: 10.1892/0891-6640(2005)19[344:ahihar]2.0.co;2.

MARKEY, B. K. et al. Microbiologia veterinária e doenças infecciosas. [S.1.]: Grupo A - Artmed, 2013. Cap. 8, pag.105-134.

RIZZI, T. et al. Effusions: Abdominal, Thoracic, and Pericardial. In: COWELL, R. L. et al. Diagnostic Cytology and Hematology. 3 ed., Missouri: Mosby Elsevier, 2008, p.235-255.

ROBINSON, N. E. and FURLOW, P. W. Anatomy of the respiratory tract. In: MCGORUM, B. C. et al. (Org.). Equine Respiratory Medicine and Surgery. Philadelphia: Saunders [Imprint] Elsevier - Health Sciences Division, 2006, p. 3-17.

URQUHART, K. A. et al. Tracheobronchial foreign body in a pony. Equine Veterinary Journal, out. 1981. v.13, n.4, p.262264. Available from: <https://beva.onlinelibrary.wiley.com/doi/ abs/10.1111/j.2042-3306.1981.tb03515.x>. Accessed: Nov. 20, 2020. doi: 10.1111/j.2042-3306.1981.tb03515.x.

WALTON, R. M. Equine Hematology. In: WALTON, R. M. (Org.). Equine Clinical Pathology. Chichester, UK: John Wiley \& Sons, Inc., 2013, p.15-35. 